\title{
Linaclotide induces secretion of cGMP from mouse colonic epithelium
}

\author{
Boris Tchernychev*, Sarah Jacobson, Caroline Kurtz, Mark Currie, Inmaculada Silos-Santiago \\ From 6th International Conference on cGMP: Generators, Effectors and Therapeutic Implications \\ Erfurt, Germany. 28-30 June 2013
}

Linaclotide is a novel receptor guanylyl cyclase $\mathrm{C}(\mathrm{GC}-\mathrm{C})$ agonist approved for treatment of abdominal pain and constipation in patients with irritable bowel syndrome with constipation (IBS-C). Linaclotide effects on bowel movements are mediated by the intracellular cGMP that is produced upon activation of GC-C. It is hypothesized that the effects of linaclotide on abdominal pain are mediated by extracellular cGMP, which was shown to decrease the activity of pain-sensing nerves [1]. Here we used an $e x$ vivo Ussing chamber assay to measure the secretion of cGMP from the mouse colonic mucosa in response to linaclotide treatment. Ion transport and epithelial barrier function were monitored by measuring short-circuit current $\left(\mathrm{I}_{\mathrm{sc}}\right)$ and trans-epithelial electrical resistance (TEER). Stimulation with linaclotide $(1 \mu \mathrm{M})$ elicited a robust short-circuit current across mouse colonic epithelium. $\mathrm{I}_{\mathrm{sc}}$ reached a maximum within ten minutes following stimulation with linaclotide and remained steady during the duration of the study $(60 \mathrm{~min})$. Treatment of colonic mucosa with linaclotide induced release of cGMP from the apical, as well as, the basolateral side of the epithelium. The time course of cGMP accumulation in the basolateral bath of the Ussing chamber was linear with an estimated cGMP secretion rate equal to $23 \mathrm{fmol} / \mathrm{min} \times \mathrm{cm}^{2}$. The trans-epithelial electrical resistance of the colonic mucosa remained high over the course of the study indicating that the barrier to diffusion of cGMP between apical and basolateral sides remained intact throughout the study. In summary, these data demonstrate that linaclotide-stimulated mouse colonic epithelium secretes cGMP from both the apical and basolateral sides and that cGMP is available in the submucosal interstitial space to inhibit colonic nociceptors.

\footnotetext{
* Correspondence: btchernychev@ironwoodpharma.com Ironwood Pharmaceuticals Inc., Cambridge, MA 02142, USA
}

Published: 29 August 2013

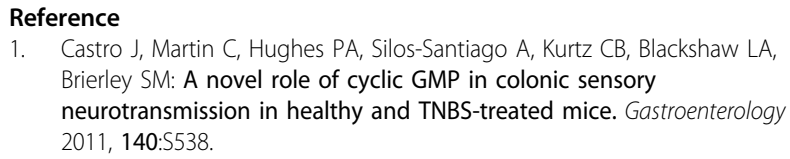

1. Castro J, Martin C, Hughes PA, Silos-Santiago A, Kurtz CB, Blackshaw LA, Brierley SM: A novel role of cyclic GMP in colonic sensory neurotransmission in healthy and TNBS-treated mice. Gastroenterology 2011, 140:S538.

doi:10.1186/2050-6511-14-S1-P70

Cite this article as: Tchernychev et al:: Linaclotide induces secretion of cGMP from mouse colonic epithelium. BMC Pharmacology and Toxicology 2013 14(Suppl 1):P70

Submit your next manuscript to BioMed Central and take full advantage of:

- Convenient online submission

- Thorough peer review

- No space constraints or color figure charges

- Immediate publication on acceptance

- Inclusion in PubMed, CAS, Scopus and Google Scholar

- Research which is freely available for redistribution

Submit your manuscript at www.biomedcentral.com/submit
() Biomed Central
C Biomed Central 